\title{
UPAYA MENINGKATKAN KEMAMPUAN MENULIS DESKRIPSI SISWA MELALUI MODEL PEMBELAJARAN LANGSUNG DI KELAS IV SDN 1 TANJUNG AGUNG KABUPATEN MUSI BANYUASIN
}

\author{
Fahirun $^{1}$, Missriani $^{2}$, Yessi Fitriani ${ }^{3}$ \\ ${ }^{1}$ SDN 1 Tanjung Agung, ${ }^{2,3}$ Universitas PGRI Palembang \\ e-mail: fahirunspd@gmail.com
}

\begin{abstract}
Abstrak - Tujuan penelitian ini adalah untuk meningkatkan kemampuan menulis deskripsi siswa kelas IV Sekolah Dasar melalui model pembelajaran langsung. Teknik pengumpulan data penelitian ini menggunakan observasi, tes, dokumentasi. Teknik analisis data penelitian ini menggunakan tes tertulis deskriptif melalui model pembelajaran langsung dan observasi untuk melihat aktivitas belajar siswa. Hasil penelitian ini menunjukkan adanya peningkatan setiap siklus. Siklus 1, rata-rata kemampuan menulis uraian siswa adalah 62,93 siswa yang tuntas sebanyak 6 siswa. Siklus 2 berjumlah 68,99 dan siklus 3 berjumlah 81,82 siswa yang tuntas sebanyak 16 siswa. Keaktifan belajar siswa siklus 1 keaktifan belajar siswa 24\%, siklus $260 \%$ dan siklus $392 \%$, siswa yang tuntas sebanyak 23 siswa.

Kata Kunci: Menulis deskripsi, Model Pembelajaran Langsung
\end{abstract}

\begin{abstract}
The purpose of this study was to improve the ability to write the description of grade IV students at Elementary School through direct instruction models.The research of the data collection techniques using observation, tests, documentation. The research of the data analysis technique uses descriptive writed tests through direct instruction models and observations to saw student learning activities. The results of this studied indicate those is an increase of each cycle. Cycle 1, the average ability to write a description of students is 62.93, students who complete as many as 6 students. Cycle 2 amounted to 68.99 and cycle 3 amounted to 81.82, students who completed as many as 16 students. Student learning activeness of cycle 1 student learning activeness of 24\%, cycle 2 of $60 \%$ and cycle 3 of 92\%, students who completed as many as 23 students.

Keywords: Descriptive Writed, Direct Instruction Models.
\end{abstract}

\section{PENDAHULUAN}

Menulis sebagai salah satu keterampilan berbahasa diakui oleh umum. Menulis merupakan keterampilan yang mensyaratkan penguasaan bahasa yang baik. Dalam belajar bahasa, menulis merupakan kemahiran tingkat lanjut. Semi (2017:14) berpendapat bahwa pengajaran menulis merupakan dasar untuk keterampilan menulis. Jadi jelas di sini bahwa membaca sangat besar manfaatnya terhadap peningkatan intelektual, cara dan watak seseorang. Pendapat lain mengatakan bahwa membaca adalah suatu proses yang dilakukan serta dipergunakan oleh pembaca untuk memperoleh pesan yang hendak disampaikan oleh penulis melalui media kata-kata atau bahasa tulis (Rahim, 2017:53).

Menurut Halim, dkk. (2014:7), keterampilan menulis adalah keterampilan mengorganisasikan dan mengekspresikan unsur-unsur sebagai berikut: (1) isi karangan, (2) bentuk karangan, (3) tata bahasa, (4) gaya atau pilihan struktur dan kosakata, dan (5) penerapan ejaan dan penggunaan tanda baca. Colderonello, dkk. (1990:74) mengatakan bahwa proses 
menulis ada lima tahapan, yaitu (1) menemukan 'inventing', (2) merencanakan 'planning', (3) membuat draf 'drafting', (4) merevisi 'revising', dan (5) memeriksa naskah 'editing'.

Salah satu bentuk kemampuan menulis adalah menulis deskripsi. Nurgiyantoro (2010:83), mengemukakan bahwa deskripsi adalah pemaparanatau penggambaran dengan kata-kata tentang suatu benda, tempat, suasana atau kejadian. Tujuan deskripsi ini agar seolah-olah pembaca "melihat" hal yang dilihatnya, dapat "mendengar" apa yang didengarnya, dapat "mencium bau" hal yang diciumnya, dapat mencicipi” sesuatu yang dimakannya, dapat "merasakan" hal yang dirasakannya, sehingga pembaca memiliki kesimpulan yang sama dengan penulis. Aktivitas menulis merupakan salah satu manifestasi kemampuan dan keterampilan berbahasa paling akhir yang dikuasai dalam pembelajaran bahasa setelah mendengarkan, membaca dan berbicara (Nurgiyantoro, 2010:84). Dalam buku yang sama, juga dijelaskan apabila dibandingkan dengan keterampilan berbahasa yang lain kemampuan menulis lebih sulit dikuasai oleh pembelajar bahasa karena kemampuan menulis menghendaki penguasaan berbagai aspek lain di luar bahasa, untuk menghasilkan paragraf atau wacana yang runtut dan padu.

Berkaitan dengan tulisan yang baik, tulisan itu sekurang- kurangnya harus mempunyai ciri-ciri: (1) mudah; (2) sederhana; (3) adanya sarana pengantar; dan
(4) tepat (Gie, 1996:83). Mudah artinya tulisan itu mudah dimengerti pembaca dan setiap pembaca menyukai karangan itu karena karangan dapat dipahami tanpa dengan susah payah. Sederhana artinya kalimat dan kata-kata yang digunakan dalam karangan tidak berlebih-lebihan. Langsung artinya karangan itu tidak berbelit-belit dalam mengungkapkan pokok pembicaraan. Tepat artinya karangan itu benar-benar dapat mencerminkan pikiran penulis sehingga dapat diterima pembaca.

Di antara aktivitas menulis adalah aktivitas menullis deskripsi yang merupakan kompetensi menulis yang sudah ada dan dimulai pada jenjang sekolah dasar. Siswa dapat mengungkapkan perasaan, ide, dan gagasannya kepada orang lain melalui kegiatan menulis deskripsi. Kemampuan menulis karangan deskripsi tidak secara otomatis dapat dikuasai oleh siswa, melainkan harus melalui latihan dan praktik yang banyak dan teratur, sehingga siswa akan lebih mudah berekspresi dalam kegiatan menulis. Sehubungan dengan itu, kemampuan menulis deskripsi harus ditingkatkan sejak kecil atau mulai dari pendidikan sekolah dasar. Apabila kemampuan menulis tidak ditingkatkan, maka kemampuan siswa untuk mengungkapkan pikiran atau gagasan melalui bentuk tulisan akan semakin berkurang atau tidak berkembang.

Sebagaimana hasil temuan peneliti dalam mengajar sehari-hari dalam proses pembelajaran Bahasa Indonesia yaitu di SDN 1 Tanjung Agung Kabupaten Musi 
Banyuasin untuk tahun pelajaran 2019/2020 dilaksanakan pada pukul 07.30 WIB sampai dengan 12.05 WIB, yang terdiri dari kelas I sampai dengan kelas VI dengan jumlah kelompok belajar sebanyak 6 rombongan belajar. Jumlah siswa yang ada sebanyak 127 siswa untuk tahun pelajaran 2019/2020.

Proses pembelajaran menulis deskripsi khususnya di kelas IV A SDN 1 Tanjung Agung Kabupaten Musi Banyuasin diberikan hanya 1 bulan sekali, dikarenakan proses pembelajaran Bahasa Indonesia mengacu kepada silabus dan Rencana Pelaksanaan Pembelajaran (RPP), sedangkan materi pokok bahasan lainpun juga harus diberikan. Hal ini mengakibatkan kemampuan menulis deskripsi siswa kurang maksimal. Proses pembelajaran menulis deskripsipun hanya berdasarkan konvensional, sehingga siswa yang mengikuti proses pembelajaran tersebut menjadi monoton. Terbukti bahwa menulis deskripsi siswa, yang telah mencapai ketuntasan belajarnya adalah sebesar $36 \%$ atau sebanyak 9 siswa, sedangkan belum mencapai hasil yang diharapkan sebanyak $64 \%$ atau sebanyak 16 siswa. Hal ini peneliti kaji, bahwa ada beberapa faktor yang menyebabkan kemampuan menulis deskripsi siswa tidak mencapai ketuntasan dalam belajar, yaitu sebagai berikut.

a Materi menulis deskripsi yang diberikan hanya satu bulan sekali kurang maksimal dan siswa tentunya sulit untuk memahaminya.

b. Siswa kurang tertarik dengan materi menulis deskripsi, dikarenakan selalu diberikan materi dengan pola dan cara yang sama (tidak bervariasi);

c. Siswa lebih banyak diberikan tugastugas, dikarenakan materi lain juga harus diberikan untuk memaksimalkan proses pembelajaran.

d Pembelajaran yang diberikan kepada siswa dalam menulis deskripsi diberikan dengan menggunakan konvensional;

e. Siswa kurang aktif dalam mengikuti pembelajaran menulis deskripsi.

Berdasarkan uraian beberapa faktor yang menyebabkan hasil belajar menulis deskripsi siswa tidak mencapai ketuntasan dalam belajar yang telah dikemukakan di atas, peneliti merasa perlu untuk menerapkan pembelajaran menulis deskripsi siswa melalui model pembelajaran langsung yang bersifat kreatif dan menyenangkan agar kemampuan menulis deskripsi siswa kelas IV di SDN 1 Tanjung Agung Kabupaten Musi Banyuasin diharapkan dapat ditingkatkan.

Peneliti menganggap bahwa model pembelajaran yang menggunakan pendekatan mengajar yang dapat membantu siswa mempelajari keterampilan dasar dan memperoleh pengetahuan langkah demi langkah adalah model pengajaran langsung. Menurut Arends (2011:39) "A teaching model that is aimed at helping student learn basic skills and knowledge that can be taught in a step-by-step fashion. For our purposes here, the model is labeled the direct instruction model". Artinya, sebuah model pengajaran yang bertujuan untuk 
membantu siswa mempelajari keterampilan dasar dan pengetahuan yang dapat diajarkan langkah-demi-langkah. Untuk tujuan tersebut, model yang digunakan dinamakan model pengajaran langsung.

Hal ini dipertegas Sudrajat (2015:10) mengemukakan bahwa model pembelajaran langsung adalah model pembelajaran yang menekankan pada penguasaan konsep dan atau perubahan perilaku dengan mengutamakan pendekatan deduktif, dengan ciri-ciri sebagai berikut: (1) transformasi dan ketrampilan secara langsung; (2) pembelajaran berorientasi pada tujuan tertentu; (3) materi pembelajaran yang telah terstuktur; (4) lingkungan belajar yang telah terstruktur; dan (5) distruktur oleh guru. Model pengajaran langsung dilandasi oleh teori belajar perilaku yang berpandangan bahwa belajar bergantung pada pengalaman termasuk pemberian umpan balik. Satu penerapan teori perilaku dalam belajar adalah pemberian penguatan. Umpan balik kepada siswa dalam pembelajaran merupakan penguatan yang merupakan penerapan teori perilaku tersebut.

Disamping itu, alasan peneliti melakukan penelitian di SDN 1 Tanjung Agung Kabupaten Musi Banyuasin dikarenakan dalam pembelajaran bahasa Indonesia khususnya menulis deskripsi belum mengindikasikan pencapaian hasil yang diharapkan. Hal ini peneliti menyadari sendiri dimana tempat peneliti mengajar dan siswa di kelas IV SDN 1 Tanjung Agung Kabupaten Musi Banyuasin pada semester ganjil tahun pelajaran 2019/2020 merupakan siswa binaan peneliti sendiri, juga di SDN 1 Tanjung Agung Kabupaten Musi Banyuasin belum ada peneliti lain yang melakukan penelitian dengan judul yang sama.

\section{METODE PENELITIAN}

Penelitian ini dilaksanakan dalam dua siklus dengan pedoman indikator keberhasilan dan apabila belum terpenuhi, maka akan dilaksanakan langkah perbaikan pada siklus selanjutnya.

Menurut Asrori (2012:63), prosedur setiap siklus terdiri dari empat tahapan, yaitu: perencanaan (planning), (2) tindakan (action), pengamatan (observasing), (4), refleksi (reflecting).

Teknik Pengumpulan Data Dalam Penelitian Ini Adalah Sebagai Berikut.

\section{Observasi}

Observasi adalah pengamatan terhadap suatu objek yang diteliti baik secara langsung maupun secara tidak langsung untuk memperoleh data yang harus dikumpulkan dalam penelitian (Satori, 2010:74). Lebih lanjut Arikunto (2010:187) mengemukakan observasi adalah suatu teknik yang dilakukan dengan cara mengadakan pengamatan secara teliti serta pencatatan secara sistematis.

Berdasarkan uraian pendapat di atas, observasi dalam penelitian tindakan kelas ini yaitu dengan melakukan pengamatan selama proses pembelajaran berlangsung. Pengamatan dilakukan pada saat pembelajaran menulis deskripsi siswa kelas IV SDN 1 Tanjung Agung Kabupaten Musi Banyuasin setelah digunakan model 
embelajaran langsung guna melihatperkembangan sebelum dan sesudah dilakukan tindakan. Penggunaan model pembelajaran langsung dalam proses menulis deskripsi siswa dapat dijadikan bahan ketika siswa pernah mengunjungi objek- objek wisata maupun tempat lainnya ataupun juga bisa melalui proses pembelajaran langsung dilakukan di dalam lingkungan sekolah, yaitu halaman SDN 1 Tanjung Agung Kabupaten Musi Banyuasin yang akan dijadikan bahan kajian siswa subjek dalam menulis deskripsi.

\section{Tes}

Tes adalah "Serentetan pertanyaan atau latihan suatu alat lain yang digunakan untuk mengukur keterampilan pengetahuan, intelegensi, kemampuan atau bakat yang dimiliki oleh individu (siswa) atau kelompok" (Arikunto, 2010). Tes dalam penelitian ini, peneliti memberikan tes pada masing- masing siklus, baik siklus pertama maupun siklus berikutnya guna untuk mengetahui kemampuan menulis deskripsi siswa melalui model pembelajaran langsung. Hasil kemampuan menulis deskripsi tersebut berpedoman kepada KKM.

Tes yang dilakukan pada siswa subjek di kelas IV SDN 1 Tanjung Agung Kabupaten Musi Banyuasin tahun pelajaran 2018/2019 adalah menulis deskripsi. Adapun ketentuan- ketentuan untuk menulis karangan adalah sebagai berikut.

a) Tema/ karangan ditentukan oleh peneliti.

b) Isi karangan boleh memilih sendiri sesuai dengan pengalaman pribadi siswa setelah melalui proses pembelajaran.

c) Karangan harus bersifat menceritakan masalah dari tema dan topik yang telah ditentukan.

d) Karangan harus menggunakan bahasa Indonesia.

e) Panjang karangan berkisar antara 200300 kata atau minimal satu sampai dengan satu setengah hal. buku siswa.

f) Karangan ditulis tangan dengan rapi.

g) Waktu yang diberikan untuk mengerjakan tugas menulis deksripsi 40 menit.

Tes ini bertujuan untuk memperoleh data tentang kemampuan menulis deskripsi siswa IV SDN 1 Tanjung Agung Kabupaten Musi Banyuasin setelah digunakan melalui model pembelajaran langsung.

\section{HASIL PENELITIAN DAN \\ PEMBAHASAN}

\section{Hasil Penelitian Siklus I}

Siklus I diberikan motivasi mengenai materi pembelajaran menulis deskripsi melalui model pembelajaran langsung. Materi yang diberikan dalam tindakan ini adalah "Gedung Sekolah Kami". Siswa disuruh membuat tulisan dengan cara mendeskripsikan hasil dari proses pembelajaran langsung dengan tema "Gedung Sekolah Kami".

Materi yang diajarkan pada siklus 1 adalah menulis deskripsi melalui model pembelajaran langsung. Tujuan yang 
hendak dicapai dalam proses pembelajaran adalah sebagai berikut.

1. Siswa mampu memahami materi yang diberikan, baik melalui proses pembelajaran secara kooperatif melalui model pembelajaran langsung dalam menulis deskripsi maupun menyampaikan ide-ide pokok pikiran siswa dalam mendeskripsikan hasil menulis deskripsi dengan tema "Gedung Sekolah Kami". Hasil dari proses pembelajaran menulis deskripsi tersebut peneliti memberikan penjelasan tentang materi pembelajaran yang hendak dicapai yaitu menulis deskripsi, kemudian siswa dituntut untuk dapat memahami objekobjek dari tema yang akan dikerjakan yaitu "Gedung Sekolah Kami". Pada materi pembelajaran ini, siswa diharapkan dapat mengemukakan tentang materi yang mereka lihat yaitu menulis deskripsi tentang "Gedung Sekolah Kami". Pelaksanaan proses pembelajaran, peneliti mencoba menjelaskan materi yang menerapkan model pembelajaran langsung untuk membangkitkan gairah aktivitas belajar siswa yang intinya adalah mendapatkan hasil belajar siswa secara maksimal dalam proses pembelajaran, yaitu kemampuan siswa dalam menulis deskripsi yang pada gilirannya siswa mampu untuk mendapatkan hasil belajar secara optimal.

2. Memberikan teguran kepada siswa yang kurang aktif dalam mengikuti proses pembelajaran pada saat diterapkan melalui model pembelajaran langsung, dan siswa yang tidak memperhatikan materi pembelajaran yang diberikan. Teguran ini dimaksudkan agar siswa memahami materi pembelajaran yang diberikan, dengan harapan untuk meningkatkan aktivitas belajar siswa dalam pembelajaran menulis deskripsi setelah diberikan pembelajaran melalui model pembelajaran langsung.

3. Memotivasi siswa yang tidak aktif mengikuti pembelajaran, dan menumbuhkembangkan aktivitas belajar menulis deskripsi sesuai dengan ide-ide siswa melalui model pembelajaran langsung.

4. Meminta dan memberikan kesempatan kepada siswa untuk bertanya tentang materi yang diberikan, serta meminta kepada siswa yang kurang aktif dalam mengikuti proses pembelajaran dan mempresentasikan dari hasil pembelajaran itu.

5. Guru dan siswa menyimpulkan materi yang telah dipelajari.

6. Memberikan tes menulis deskripsi pada tindakan siklus I.

Pada tahap ini, peneliti melaksanakan pengamatan atau observasi terhadap pelaksanaan pembelajaran dengan menggunakan lembar observasi yang telah dibuat. Pengamatan dilakukan oleh peneliti sendiri. Hasil observasi terhadap pelaksanaan pembelajaran pada siklus 1 dapat peneliti uraikan pada tabel berikut ini. 
Hasil Observasi Aktivitas Belajar Siswa

\section{Pada Siklus I}

\begin{tabular}{|c|l|r|r|}
\hline No. & \multirow{2}{*}{$\begin{array}{l}\text { Keterlibatan } \\
\text { Siswa dalam } \\
\text { Pembelajaran }\end{array}$} & \multicolumn{2}{|c|}{ Siklus Pertama } \\
\cline { 3 - 4 } & $\begin{array}{l}\text { Jumlah } \\
\text { Siswa }\end{array}$ & Persentase \\
\hline 1 & Terlibat Aktif & 6 & $24 \%$ \\
\hline 2 & Terlibat Pasif & 9 & $36 \%$ \\
\hline 3 & Tidak Terlibat & 10 & $40 \%$ \\
\hline & & $\mathbf{2 5}$ & $\mathbf{1 0 0 \%}$ \\
\hline
\end{tabular}

Keterangan:

1) Terlibat aktif, artinya aktivitas hasil belajar siswa terlibat aktif menyimak dengan sungguh- sungguh materi pembelajaran yang diberikan, aktivitas hasil belajar siswa mulai terlihat aktif dalam mengikuti pembelajaran yang berkaitan dengan materi menulis deskripsi melalui model pembelajaran langsung, siswa mulai aktif untuk menjawab pertanyaan yang berkenaan dengan materi pembelajaran yang diberikan.

2) Terlibat pasif, artinya aktivitas hasil belajar siswa terlihat pasif menyimak dengan sungguh- sungguh, siswa pasif dalam menjawab pertanyaan yang diberikan guru, dan siswa menjawab pertanyaan seadanya.

3) Tidak terlibat, artinya aktivitas hasil belajar siswa tidak ada, dan siswa hanya duduk dan diam saja, aktivitas belajar siswa tidak terlihat untuk melakukan kegiatan pembelajaran setelah diberikan melalui model pembelajaran langsung, dan siswa hanya diam saja, tidak bertanya maupun menjawab pertanyaan.
Berdasarkan uraian pada tabel di atas, hasil observasi aktivitas hasil belajar pada siklus I, diketahui bahwa aktivitas belajar siswa yang terlibat aktif dalam proses pembelajaran sebanyak 6 orang siswa atau $24 \%$, aktivitas hasil belajar siswa yang terlibat pasif sebanyak 9 siswa atau $36 \%$, dan aktivitas hasil belajar siswa yang tidak terlibat sebanyak 10 siswa atau $40 \%$.

\section{Hasil Penelitian Siklus II}

Hasil perbandingan nilai data tes kemampuan menulis deskripsi siswa kelas IV SD Negeri 1 Tanjung Agung Kabupaten Musi Banyuasin melalui model pembelajaran langsung siklus 1 yang dikoreksi oleh pemeriksa 1 , pemeriksa 2 dan pemeriksa 3, diketahui nilai yang diperoleh siswa sebesar 1573,33 atau rata-rata sebesar 62,93. Siswa yang mencapai ketuntasan menulis deskripsi siswa kelas IV SD Negeri 1 Kabupaten Musi Banyuasin melalui model pembelajaran langsung siklus $1 \geq 70$ berdasarkan KKM sebanyak 6 orang siswa atau rata-rata persentase ketuntasan sebesar $24 \%$. Nilai tertinggi dicapai siswa dalam menulis deskripsi siswa kelas IV SD Negeri 1 Tanjung Agung Kabupaten Musi Banyuasin melalui model pembelajaran langsung siklus sebesar 72,67 dan terendah sebesar 55,33, belum mencapai ketuntasan belajar.

Kegiatan utama yang dilakukan siswa pada siklus 2 adalah memperbaiki menulis deskripsi yang ditulis oleh siswa pada siklus 1. Pembelajaran perevisian ini berlangsung selama 2 x 35 menit. Kegiatan didahului dengan penginformasian tujuan menulis 
deskripsi berdasarkan tema yang sudah ditentukan yaitu "Sawah Ku" sebagai usaha untuk memotivasi siswa. Setelah itu, proses pembelajaran dilakukan dengan menerapakan model pembelajaran langsung dalam memotivasi ide/gagasan siswa dalam menulis deskripsi yang dikaitkan dengan dunia nyata dalam kehidupan sehari- hari siswa.

Agar proses pembelajaran menulis deskripsi siswa kelas IV SD Negeri 1 Tanjung Agung Kabupaten Musi Banyuasin melalui model pembelajaran langsung berjalan sesuai dengan yang diharapkan, maka peneliti melakukan langkah- langkah tindakan sebagai berikut.

\section{1) Perencanaan}

Pada tahap perencanaan ini, dilakukan sebagai berikut.

a. Mempersiapkan perangkat pembelajaran

- Membuat silabus RPP

- Menyusun dan merancang skenario pembelajaran

- Membuat alat evaluasi (soal tes) untuk tahap siklus 2.

b. Peneliti mempersiapkan diri lebihbaik lagi dalam menyajikan/mengambil permasalahan terbuka yang memiliki beberapa jawaban atau penyelesaian benar

c.Peneliti memberikan penekanan materi pembelajaran kepada siswa tentang teknik menulis deskripsi yang berkaitan dengan kelengkapan unsur deskripsi harus sesuai dengan judul yang telah ditetapkan, ejaan dilihat pada penggunaan huruf besar di awal kalimat, dan penggunaan tanda baca (titik, koma) yang tepat.

d. Mengatasi siswa yang tidak memperhatikan pelajaran dengan memberikan teguran agar betul-betul menyimak materi pembelajaran menulis deskripsi melalui model pembelajaran langsung.

e. Mengatasi siswa yang tidak aktif dalam mengikuti proses pembelajaran pada saat diterapkan pembelajaran melalui model pembelajaran langsung, dan meminta siswa untuk mempresentasikannya di depan kelas.

f. Memotvasi siswa yang belum berani menyampaikan gagasannya dan bertanya apabila ada kesulitan.

\section{2) Pelaksanaan}

Sebelum pelaksanaan pembelajaran dengan menggunakan model pembelajaran langsung, peneliti juga memperhatikan kegiatan aktivitas pembelajaran yang telah dilakukan siswa. Pelaksanaan pembelajaran dilakukan sebagai berikut.

a) Pada materi pembelajaran menulis deskripsi melalui model pembelajaran langsung lebih ditekankan kembali yang dikaitkan dengan dunia nyata dalam kehidupan sehari-hari.

b) Memberikan teguran kepada siswa jika masih ada yang tidak memperhatikan

c) Memotivasi siswa yang tidak aktif dalam mengikuti proses pembelajaran.

d) Memberikan arahan kepada siswa berkemampuan tinggi agar membantu 
siswa berkemampuan sedang atau rendah.

e) Meminta dan memberikan kesempatan kepada siswa untuk bertanya tentang materi yang diberikan.

f) Meminta siswa mempelajari terlebih dahulu materi yang sudah dipelajari pada pertemuan sebelumnya.

g) Memberikan tes akhir pada siklus II.

\section{3) Observasi}

Pada tahap ini, penulis melaksanakan pengamatan atau observasi terhadap pelaksanaan pembelajaran dengan menggunakan lembar observasi yang telah dibuat.

Hasil Observasi Aktivitas Belajar Siswa Pada Siklus 2

\begin{tabular}{|c|l|c|c|}
\hline No. & \multirow{2}{*}{$\begin{array}{l}\text { Keterlibatan Siswa } \\
\text { dalam Pembelajaran }\end{array}$} & \multicolumn{2}{|c|}{ Siklus Pertama } \\
\cline { 3 - 4 } & & $\begin{array}{l}\text { Jumlah } \\
\text { Siswa }\end{array}$ & Persentase \\
\hline 1 & Terlibat Aktif & 15 & $60 \%$ \\
\hline 2 & Terlibat Pasif & 7 & $28 \%$ \\
\hline 3 & Tidak Terlibat & 3 & $12 \%$ \\
\hline & Jumla & $\mathbf{2 5}$ & $\mathbf{1 0 0 \%}$ \\
\hline
\end{tabular}

Keterangan:

1) Terlibat aktif, artinya aktivitas hasil belajar siswa terlibat aktif menyimak dengan sungguh- sungguh materi pembelajaran yang diberikan, aktivitas hasil belajar siswa mulai terlihat aktif dalam mengikuti pembelajaran yang berkaitan dengan materi menulis deskripsi melalui model pembelajaran langsung, siswa mulai aktif untuk menjawab pertanyaan yang berkenaan dengan materi pembelajaran yang diberikan.

2) Terlibat pasif, artinya aktivitas hasil belajar siswa terlihat pasif menyimak dengan sungguh-sungguh, siswa pasif dalam menjawab pertanyaan yang diberikan guru, dan siswa menjawab pertanyaan seadanya.

3) Tidak terlibat, artinya aktivitas hasil belajar siswa tidak ada, dan siswa hanya duduk dan diam saja, aktivitas belajar siswa tidak terlihat untuk melakukan kegiatan pembelajaran setelah diberikan melalui model pembelajaran langsung, dan siswa hanya diam saja, tidak bertanya maupun menjawab pertanyaan.

\section{Hasil Penelitian Siklus 3}

Hasil penelitian pada siklus 2, ternyata nilai yang diperoleh siswa kelas IV SD Negeri 1 Tanjung Agung Kabupaten Musi Banyuasin melalui model pembelajaran langsung Tahun Pelajaran 2019/2020 dalam menulis deskripsi melalui model pembelajaran langsung belum mencapai ketetapan yang diharapkan. Terbukti dari hasil analisis data tes kemampuan menulis deskripsi siswa kelas IV SD Negeri 1 Tanjung Agung Kabupaten Musi Banyuasin melalui model pembelajaran langsung siklus 2 yang dikoreksi oleh pemeriksa 1 , pemeriksa 2 dan pemeriksa 3, diketahui nilai yang diperoleh siswa sebesar 1724,67 atau rata-rata sebesar 68,99 . Siswa yang mencapai ketuntasan menulis deskripsi siswa IV SD Negeri 1 Tanjung Agung Kabupaten Musi Banyuasin melalui

model pembelajaran langsung siklus $2 \geq 70$ berdasarkan KKM sebanyak 16 orang siswa atau rata-rata persentase ketuntasan sebesar $64 \%$. Nilai tertinggi 
dicapai siswa dalam menulis deskripsi siswa IV SD Negeri 1 Tanjung Agung Kabupaten Musi Banyuasin melalui model pembelajaran langsung pada siklus sebesar 71,33 dan terendah sebesar 63,33.

Proses pembelajaran siklus 3 , penulis berusaha untuk memperbaiki hasil belajar siswa yaitu menulis deskripsi melalui model pembelajaran langsung, dengan cara memberikan pemahaman tentang unsurunsur menulis deskripsi yang harus berkaitan dengan judul/tema, kalimat yang diuraikan harus berkaitan dan penggunaan kata yang tepat serta berdasarkan ejaan yang benar. Namun proses pembelajaran menulis deskripsi siswa kelas IV SD Negeri 1 Tanjung Agung Kabupaten Musi Banyuasin melalui model pembelajaran langsung pada siklus belum berjalan secara maksimal. Masih ada beberapa faktor penghambat tidak tercapainya nilai yang diharapkan.

Berdasarkan faktor-faktor yang menyebabkan belum tercapainya nilai KKM menulis deskripsi siswa kelas IV SD Negeri 1 Tanjung Agung Kabupaten Musi Banyuasin melalui model pembelajaran langsung pada siklus 1 , maka peneliti melanjutkan pada tindakan berikutnya yaitu pada siklus 3, dan terlebih dahulu penulis melakukan refleksi untuk mengetahui faktor-faktor penghambat tidak berhasilnya proses pembelajaran menulis deskripsi siswa kelas IV SD Negeri 1 Tanjung Agung Kabupaten Musi Banyuasin melalui model

pembelajaran langsung pada siklus 2, sehingga hasil yang diharapkan dalam menulis deskripsi siswa kelas IV SD Negeri 1 Tanjung Agung Kabupaten Musi Banyuasin melalui model pembelajaran langsung benar-benar mencapai ketuntasan hasil belajar yang diharapkan.

Proses pelaksanaan pada siklus 3 ini adalah menindaklanjuti kelemahan dan kekurangan yang terdapat pada siklus 2 . Pada siklus 2 proses pembelajaran yang diberikan menindaklanjuti kelemahan yang terjadi pada proses pembelajaran siklus 1 dalam menulis deskripsi dan proses menulis deskripsi ditetapkan berdasarkan tingkat kemampuan siswa, maka pada siklus 2 adalah refleksi dan analisis menulis deskripsi siswa.

Untuk tindakan pada siklus 3, penulis melakukan strategi pembelajaran dengan mengkolaborasikan proses pembelajaran menulis deskripsi melalui pendekatan konvensional dan pendekatan kontekstual. Pembelajaran perevisian ini berlangsung selama 2 x 35 menit.

Agar proses pembelajaran menulis deskripsi maka penulis melakukanlangkahlangkah tindakan sebagai berikut.

Pada tahap perencanaan ini, dilakukan sebagai berikut.

a. Mempersiapkan perangkat pembelajaran

b. Mempersiapkan diri lebih baik lagi

c. Mengatasi siswa yang tidak memperhatikan pelajaran dengan memberikan teguran

d. Mengatasi siswa yang tidak aktif dalam mengikuti proses pembelajaran Pelaksanaan pembelajaran dilakukan 
sebagai berikut.

a) Pada materi pembelajaran menulis deskripsi melalui model pembelajaran langsung lebih ditekankan kembali yang dikaitkan dengan dunia nyata dalam kehidupan sehari-hari.

b) Memberikan teguran kepada siswa jika masih ada yang tidak memperhatikan materi pembelajaran yang diberikan.

c) Memotivasi siswa yang tidak aktif.

d) Memberikan arahan kepada siswa yang berkemampuan tinggi agar dapat membantu dan bekerjasama dengan

Hasil Observasi Aktivitas Belajar Siswa

Pada Siklus 3

\begin{tabular}{|c|l|r|r|}
\hline \multirow{2}{*}{ No. } & \multirow{2}{*}{$\begin{array}{l}\text { Keterlibatan } \\
\text { Siswa dalam } \\
\end{array}$} & Pembelajaran & \multicolumn{2}{|c|}{ Siklus Pertama } \\
\cline { 3 - 4 } & & $\begin{array}{l}\text { Jumlah } \\
\text { Siswa }\end{array}$ & Persentase \\
\hline 1 & Terlibat Aktif & 23 & $92 \%$ \\
\hline 2 & Terlibat Pasif & 2 & $8 \%$ \\
\hline 3 & Tidak Terlibat & 0 & $0 \%$ \\
\hline & & $\mathbf{2 5}$ & $\mathbf{1 0 0 \%}$ \\
\hline
\end{tabular}

Berdasarkan uraian pada tabel $4.11 \mathrm{di}$ atas, hasil observasi aktivitas hasil belajar pada siklus 3, menunjukkan hasil yang baik dan cukup memuaskan. Hal ini diketahui aktivitas belajar siswa yang terlibat aktif dalam proses pembelajaran sebanyak 23 orang siswa atau $92 \%$, aktivitas hasil belajar siswa yang terlibat pasif sebanyak 2 siswa atau 8\%, dan aktivitas hasil belajar siswa yang tidak terlibat tidak ada. Artinya boleh dikatakan pada proses pembelajaran menulis deskripsi siswa kelas IV SD Negeri 1 Tanjung Agung Kabupaten Musi Banyuasin siswa yang berkemampuan sedang atau rendah.

e) Memberikan kesempatan kepada siswa bertanya tentang materi yang diberikan.

f) Meminta siswa mempelajari terlebih dahulu materi yang sudah dipelajari pada pertemuan sebelumnya.

g) Memberikan tes akhir pada siklus 3.

Pada tahap ini, penulis melaksanakan pengamatan terhadap pelaksanaan pembelajaran dengan menggunakan lembar observasi yang telah dibuat.

melalui model pembelajaran langsung semua siswa terlibat aktif.

\section{PEMBAHASAN}

Berdasarkan perbandingan aktivitas belajar siswa pada saat proses pembelajaran menulis deskripsi siswa kelas IV SD Negeri 1 Tanjung Agung Kabupaten Musi Banyuasin melalui model pembelajaran langsung pada tabel 4.12 di atas, diketahui aktivitas belajar siswa mengalami peningkatan yang cukup positif. Hal ini terlihat dari tabel tersebut, pada siklus 1 siswa yang terlibat aktif sebanyak 6 orang 
siswa atau $24 \%$, kemudian meningkat pada siklus 2 yaitu sebanyak 15 orang siswa atau $60 \%$, dan mengalami peningkatan kembali pada siklus 3, yaitu sebanyak 23 orang siswa atau $92 \%$.

Berdasarkan perbandingan analisis data tes menulis deskripsi dari setiap siklus seperti terlihat pada tabel 4.17 , diketahui bahwa analisis data tes menulis deskripsi siswa kelas IV SD Negeri 1 Tanjung Agung Kabupaten Musi Banyuasin melalui model pembelajaran langsung pada siklus 1 diperoleh nilai sejumlah 1573,33 dengan rata-rata sebesar 62,93. Siswa yang mencapai $\mathrm{KKM} \geq 70$ sebanyak 6 orang siswa atau rata- rata persentase pencapaian ketuntasan sebesar $24 \%$.

Setelah dilakukan refleksi untuk dilakukan tindakan berikutnya, yaitu pada siklus 2, hasil pemerolehan nilai siswa mengalami peningkatan yang cukup positif, yaitu sebesar 1724,67 atau rata-rata pencapaian hasil belajar siswa sebesar 68,99 . Siswa yang mencapai KKM $\geq 70$ sebanyak 16 orang siswa atau rata-rata persentase pencapaian ketuntasan sebesar 64\%. Hal ini menunjukkan terdapat peningkatan yang cukup positif, walaupun hasil belajar siswa yang diharapkan belum mencapai hasil yang ditetapkan.

Terbukti dari hasil kolaborasi melalui pendekatan konvensional dan model pembelajaran langsung, siswa lebih memahami materi yang disampaikan dalam menulis deskripsi melalui model pembelajaran langsung. Hasil yang diperoleh pada siklus 3 diketahui pemerolehan nilai siswa sebesar 2031,97 atau rata-rata pencapaian hasil belajar siswa sebesar 81,28 . Siswa yang mencapai KKM $\geq 70$ sebanyak 23 orang siswa atau rata- rata persentase pencapaian ketuntasan sebesar 92\%. Hal ini menunjukkan terdapat peningkatan yang cukup positif dan baik sekali.

Dengan demikian, hasil yang diperoleh dalam menulis deskripsi telah mencapai nilai yang ditetapkan, maka peneliti tidak melanjutkan pada tindakan berikutnya dikarenakan nilai yang diperoleh dalam menulis deskripsi sudah mencapai nilai $\mathrm{KKM} \geq 70$, dan pencapaian nilai secara klasikal sebesar $85 \%$ dapat dikatakan sudah tercapai, dikarenakan ketuntasan belajar siswa sebesar $92 \%$.

Jadi, dengan menulis dapat melahirkan pengetahuan, pengalaman, jenis tulisan sehingga penyajiannya sesuai dengan konvensi tulisan. Untuk itu diperlukan pengetahuan dan pengalaman yang luas, kemampuan mengendalikan emosi, menata serta mengembangkan ide dengan daya nalar dalam berbagai level berfikir. Menulis juga dapat menumbuhkan keberanian. Pada saat menulis akan timbul rasa keberanian yang meliputi pemikiran, perasaan, sikap, dan gaya untuk disampaikan kepada pembaca. Karena itu penulis harus berani menerima berbagai keritikan dari pembaca.

Berdasarkan perbandingan aktivitas belajar siswa pada saat proses pembelajaran menulis deskripsi diketahui aktivitas belajar siswa mengalami peningkatan yang cukup 
positif. Hal ini terlihat dari tabel tersebut, pada siklus 1 siswa yang terlibat aktif sebanyak 6 orang siswa atau $24 \%$, kemudian meningkat pada siklus 2 yaitu sebanyak 15 orang siswa atau $60 \%$, dan mengalami peningkatan kembali pada siklus 3, yaitu sebanyak 23 orang siswa atau $92 \%$.

Siswa yang terlibat pasif pada saat proses pembelajaran menulis deskripsi, terlihat pada perbandingan tersebut mengalami peningkatan yang baik. Hal ini terlihat pada tabel tersebut pada siklus 1 siswa yang pasit sebanyak 9 orang siswa atau $36 \%$, kemudian berkurang pada siklus 2, yaitu sebanyak 7 orang siswa atau $28 \%$, kemudian berkurang kembali pada siklus 3, yaitu sebanyak 2 orang siswa atau $8 \%$. Hal ini membuktikan bahwa siswa mulai memperhatikan kegiatan proses pembelajaran menulis deskripsi melalui model pembelajaran langsung lebih baik lagi.

Siswa yang tidak terlibat pada proses pembelajaran menulis deskripsi pada siklus 1 berjumlah sebanyak 10 orang siswa atau $40 \%$. Siswa masih banyak yang tidak memperhatikan, bahkan ada beberapa siswa yang masih terlihat mengobrol dengan temannya, kemudian pada siklus 2 setelah diberikan pengarahan dan diberikan teguran, siswa mulai tampak memperhatikan kegiatan proses pembelajaran tersebut. Hal ini terbukti siswa yang tidak terlibat mulai berkurang, yaitu sebanyak 3 orang siswa atau $12 \%$. Namun proses pembelajaran yang diberikan kepada siswa sekolah dasar tentu tidak sama dengan siswa sekolah menengah.

Hasil analisis data tes kemampuan menulis deskripsi juga mengalami peningkatan yang cukup baik. Hal ini terbukti dari berdasarkan perbandingan analisis data tes menulis deskripsi dari setiap, diketahui bahwa analisis data tes kemampuan menulis deskripsi siswa kelas IV SD Negeri 1 Tanjung Agung Kabupaten Musi Banyuasin melalui model pembelajaran langsung pada siklus 1 diperoleh nilai sejumlah 1573,33, dengan rata- rata hasil belajar sebanyak 25 siswa sebesar 62,93. Siswa yang mencapai KKM $\geq 70$ sebanyak 6 orang siswa atau rata-rata persentase pencapaian ketuntasan sebesar $24 \%$.

Setelah dilakukan refleksi untuk dilakukan tindakan berikutnya, yaitu pada siklus 2, hasil pemerolehan nilai siswa sebesar 1724,67 atau rata-rata pencapaian hasil belajar siswa sebesar 68,99. Siswa yang mencapai $\mathrm{KKM} \geq 70$ sebanyak 16 orang siswa atau rata- rata persentase pencapaian ketuntasan sebesar $64 \%$. Hal ini menunjukkan terdapat peningkatan yang cukup positif, walaupun hasil belajar siswa yang diharapkan belum mencapai hasil yang ditetapkan.

Terbukti dari hasil kolaborasi melalui pendekatan konvensional dan model pembelajaran langsung, siswa lebih memahami materi yang disampaikan dalam menulis deskripsi melaluimodel pembelajaran langsung. Hasil yang diperoleh pada siklus 3 diketahui 
pemerolehan nilai siswa sebesar 2031,97 atau rata-rata pencapaian hasil belajar siswa sebesar 81,28 . Siswa yang mencapai KKM $\geq 70$ sebanyak 23 orang siswa atau rata- rata persentase pencapaian ketuntasan sebesar 92\%. Hal ini menunjukkan terdapat peningkatan yang cukup positif dan baik sekali. Maka peneliti tidak melanjutkan pada tindakan berikutnya dikarenakan nilai yang diperoleh dalam menulis deskripsi sudah mencapai nilai yang ditetapkan. Hal ini diketahui dari peningkatan hasil belajar siswa yang mencapai $\mathrm{KKM} \geq 70$ dari setiap siklus.

Berdasarkan hasil penelitian ternyata melalui pendekatan kontekstual dapat meningkatkan kemampuan menulis deskripsi siswa kelas IV SD Negeri 1 Tanjung Agung Kabupaten Musi Banyuasin melalui model pembelajaran langsung. Siswa lebih bergairah dalam proses pembelajaran. Ide-ide pokok pikiran terfokus kepada objek yang disajikan. Sebelumnya siswa pernah melihat objek yang di tuju dan menuangkan ide-ide pokok pikiran siswa itu ke dalam bentuk tulisan. Dengan mengacu kepada kelebihan dan kekurangan pada proses pembelajaran melalui pendekatan kontekstual, penulis berupaya untuk dapat memberikan hasil yang terbaik kepada peserta didik dengan cara menghidupkan suasana belajar yang dikaitkan dunia nyata dalam kehidupan sehari-hari.

\section{KESIMPULAN}

Berdasarkan hasil penelitian tentang upaya meningkatkan kemampuan menulis deskripsi siswa kelas IV SD Negeri 1 Tanjung Agung Kabupaten Musi Banyuasin melalui model pembelajaran langsung dapat disimpulkan bahwa melalui model pembelajaran langsung dapat meningkatkan kemampuan menulis deskripsi. Siswa lebih bergairah dalam proses pembelajaran. Ideide pokok pikiran terfokus kepada objek yang disajikan. Sebelumnya siswa pernah melihat objek yang di tuju dan menuangkan ide-ide pokok pikiran siswa itu ke dalam bentuk tulisan. Dengan mengacu kepada kelebihan dan kekurangan pada proses pembelajaran melalui model pembelajaran langsung, dapat memberikan hasil yang terbaik kepada peserta didik dengan cara menghidupkan suasana belajar yang dikaitkan dunia nyata dalam kehidupan sehari-hari.

Berdasarkan perbandingan aktivitas belajar siswa pada saat proses pembelajaran menulis deskripsidiketahui aktivitas belajar siswa mengalami peningkatan yang cukup positif. Hal ini terlihat pada siklus 1 siswa yang terlibat aktif sebanyak 6 orang siswa atau $24 \%$, kemudian meningkat pada siklus 2 yaitu sebanyak 15 orang siswa atau $60 \%$, dan mengalami peningkatan kembali pada siklus 3, yaitu sebanyak 23 orang siswa atau $92 \%$.

Berdasarkan perbandingan analisis data tes menulis deskripsi dari setiap siklus, diketahui bahwa analisis data tes menulis deskripsi pada siklus 1 diperoleh nilai sejumlah 1573,33 dengan rata-rata sebesar 62,93. Siswa yang mencapai KKM $>70$ sebanyak 6 orang siswa atau rata-rata 
persentase pencapaian ketuntasan sebesar 24\%. Kemudian pada siklus 2, hasil pemerolehan nilai siswa mengalami peningkatan yang cukup positif, yaitu sebesar 1724,67 atau rata-rata pencapaian hasil belajar siswa sebesar 68,99. Siswa yang mencapai $\mathrm{KKM} \geq 70$ sebanyak 16 orang siswa atau rata- rata persentase pencapaian ketuntasan sebesar $64 \%$. Hal ini menunjukkan terdapat peningkatan yang cukup positif, walaupun hasil belajar siswa yang diharapkan belum mencapai hasil yang ditetapkan.

Selanjutnya pada siklus 3 diketahui pemerolehan nilai siswa sebesar 2031,97 atau rata-rata pencapaian hasil belajar siswa sebesar 81,28 . Siswa yang mencapai KKM $\geq 70$ sebanyak 23 orang siswa atau rata-rata persentase pencapaian ketuntasan sebesar 92\%. Hal ini menunjukkan terdapat peningkatan yang positif.

\section{DAFTAR PUSTAKA}

Arikunto, Suharsimi, 2010. Prosedur Penelitian Suatu Pendekatan Praktek. Jakarta: Rineka Cipta.

Asrori. Mohammad. 2012. Penelitian Tindakan Kelas. Bandung: Wacana Prima.

Arends, Bloom, B.S. 2011. Taxonomy of Educational Objectives, The Classification of Educational Goals, Hand Book 1: Cognitive Domain. USA : Longman Inc.

Gie. The Liang. 2010. Pengantar Dunia Karang Mengarang. Yogyakarta: Liberty.

Halim, Amran, dkk. 2014. Ujian Bahasa. Bandung: Ganaco NV.

Nurgiyantoro, Burhan. 2010. Pengajaran
Bahasa dan Sastra Indonesia.

Yogyakarta: BPFE.

Rahim, Farida. 2017. Pengajaran Membaca di Sekolah Dasar dan Menengah. Jakarta: Bumi Aksara.

Satori, Muhammad. 2010. Penelitian Kualitatifdan Pendekatannya. Bandung: Alfabeta.

Semi, Atar. 2007. Dasar-Dasar Keterampilan Menulis. Bandung: Angkasa.

Sudrajat. 2015. Model-Model, Media, dan Strategi Pembelajaran Kontekstual (Inovatif). Bandung: Yrama Widya 